\section{Anoxia and Cerebral Water Content in the Adult Rat}

Although there is adequate evidence that anoxia can damage the brain, the precise method by which it does so is not known. It has been suggested that deprivation of oxygen can lead to death of the cell by direct action on the neurone itself ${ }^{1}$. However, an alternative mechanism has been postulated by Lindenberg, namely, that cerebral œdema follows anoxia and this in turn leads to interference with the blood supply of the nerve cells in certain vulnerable areas ${ }^{2}$.

Anoxia in man and experimental animals is followed by an increase in water content of the brain ${ }^{3-5}$; but the importance of this in relation to the pathogenesis of brain damage is not understood. This communication describes experiments in which the effects of post-anoxic cerebral œdema and cerebral odema induced by administration of water were compared, in order to examine some of the possible factors involved in this problem.

The experimental animals were white Wistar rats of either sex, weighing 220-300 g. Unilateral anoxic forebrain lesions were induced in 50 animals by the method of Levin $\theta^{6}$, in which the right common carotid artery in the neck was ligated under ether anæsthesia, and the animal exposed to an atmosphere of nitrogen with a sufficient admixture of air to maintain regular respiration but keep the animal comatose. This was maintained for $45 \mathrm{~min}$. More than 70 per cent of the surviving animals wero made hemiplegic by this procedure.

At $24 \mathrm{~h}$ the brains of the survivors showed swelling of the right forebrain with displacement of the midline structure to the left. There was neuronal degeneration in the cerobral cortex and hippocampus of the right hemisphere, with nerve cell loss especially in the hippocampus. Proliferation of microglia and astroglia was also seen. 60 per cent of the animals did not survive the first $24 \mathrm{~h}$. Some of these died in the nitrogen and death was preceded by fits in about half of them. The rest died 10-20 h after the anoxic episode, and all had convulsions within $2 \mathrm{~h}$ before death. No neuronal loss was observed in these rats, but there was shrinking and pycnosis of the cells of tho right hippocampus.

A further similar set of experiments was porformed, but nine animals were killed immediately after the onset of fits and the brain removed. The water content of the left and right halves of the forebrains was determinod by weighing immediately after drying to constant weight at $110^{\circ} \mathrm{C}$. The normal water content was similarly determined in the brains of untreated rats. Fits during the anoxic episode were not accompanied by cerebral œdema. However, all rats developing this disturbance $10-20 \mathrm{~h}$ after anoxia had a significant increase in cerebral water content $(t=6.5, P<0.001)$ (Table 1$)$.

Table 1. Water Content of Forebrains of ADULT Rats suffering FROM CONVULSIONS FOLLOWING WATER ADMINISTRATION (150-175 ML/KG INTRAPERITONEALLY) AND ANOXIC-ISCHAEMIC BRAIN INJURY

(Mean values given \pm 1 standard deviation, expressed as $g$ water/g wet weight of tissue Convuisions Control administration

Convulsions after anoxic-ischæmia $\begin{array}{lccc}\begin{array}{l}\text { Water content of } \\ \text { forebrain }\end{array} & 78 \cdot 4 \pm 0.4 & 81 \cdot 0 \pm 0.9 & \begin{array}{c}\text { Left hemisphere } 78 \cdot 3 \pm 1 \cdot 0 \\ \text { Right hemisphere } 81 \cdot 9 \pm 1.3\end{array} \\ \text { No. of animals } & 7 & 7 & 9\end{array}$

In the final set of experiments cerebral œdema was produced by the administration of water alone. Convulsions were induced in adult rats by the intraperitoneal injection of $150-175 \mathrm{ml} . / \mathrm{kg}$ of distilled water, $10 \mathrm{~min}$ after intramuscular injection of $1 \mathrm{U}$. of vasopressin B.P. The average water content of the brain at the commencement of fits was found to be $81.0 \pm 0.9$ per cent (seven animals). At this stage further injections of water were found to be fatal. $24 \mathrm{~h}$ after this, six animals were killed and the brain examined histologically. No loss or degeneration of nerve cells, or glial reaction, was seen.
These findings indicate that, in the rat, cerebral œdema follows both anoxic-ischæmic encephalopathy and overhydration. The results suggest that convulsions and subsequent death in the early post-anoxic period could be due to an increase in the cerebral water content alone, because in both the anoxic and overhydrated groups the degree of cedema was similar when convulsions began. Previous work in this laboratory supports this interpretation $^{5}$, as it was shown that thore was significantly fewer deaths from severe anoxic-ischæmic encephalopathy following administration of 30 per cent urea, which decreased the degree of cerebral œdema in all affected animals.

Cerebral cedema was not found in animals dying during the initial anoxic episode, in whom other metabolic or physiological factors must cause death. As degeneration and loss of nerve cells did not follow cerebral oedema produced by water administration, it may be concluded. that brain swelling alone cannot lead to the destruction of neurons. This does not necessarily disprove Lindenberg's hypothesis, because anoxic brain injury could be the consequence of several factors acting together, and in the presence of circulatory and metabolic disturbances, œdema could potentiate their effect.

This work was supported by the Spastics Society.

Pædiatric Research Unit, Carole P. Hills

Guy's Hospital Medical School, London, S.E.1.

${ }^{1}$ Scholtz, W., Verh. deutsch. Ges. Kreislaufforsch., 19, 52 (1953).

${ }^{2}$ Lindenberg, R., J. Neuropath., 14, 223 (1955).

${ }^{3}$ Richardson, J. C., Chambers, R. A., and Heywood, P. M., Arch. Neurol., 1, $178(1959)$.

4 Gunn, C. G., Williams, G. R., and Parker, I. T., J. Surg. Res., 2, 141 (1962). s Spector, R. G., Brit. J. Exp. Path., 42, 623 (1961),

' Levine, S., Amer. J. Path., 36, 1 (1960).

\section{HISTOCHEMISTRY}

\section{Changes of Coenzyme (TPN) Diaphorase and TPN-linked Dehydrogenase during Axonal Reaction of the Nerve Cell}

Examination of the axonal reaction of the nerve cell has revealed a high level of metabolic processes. Lipid, protein and RNA content ${ }^{1,2}$, increase and changes in the activity of various enzymes have been described $^{1,3,5,6,8}$. Most of the histochemical investigations of the enzymes in this field were carried out on anterior horn cells or on dorsal root ganglia after cutting the sciatic nerve. A disadvantage of this is the normal variability of enzymatic activity, especially in the spinal ganglia. Difficulty is also encountered in cryostat material in differentiating a normal cell from a chromatolytic cell.

In order to avoid these difficulties, investigations were carried out on the nucleus facialis after unilateral transection of the nerve.

30 adult guinea pigs were used. The $n$. facialis was cut at its exit from the skull at the foramen stylomastoideum. Animals were killed after $1,3,5,6,7,8,9,10$ days and after $2,3,4,5,6,7,8,10,14$ weeks.

$20-\mu$ thick cryostat (model Dittes-Duspiva) sections were incubated with the appropriate substrate and the tetrazolium salt nitro-BT or tetra-nitro-BT according to the technique of Nachlas et al.

The following enzymes were investigated: TPNdiaphorase (TPN-D), the dehydrogenase of 6-phosphogluconate (6-PG) and glucose-6-phosphate (G-6-P). Activity of TPN-D, which is very weak in normal cells of the nucleus facialis, increasod significantly from 5--50 days. During this interval, G-6-P-dehydrogenase shows a marked increase of enzymatic activity while that of 6-PG-dehydrogenase increased slightly. Changes in the activity of TPN-D and G-6-P-dehydrogenase were relatively stronger and more persistent than DPN-diaphorase and DPN-linked dehydrogenasos. 